\title{
ANALISIS KONSIKWENSI TERHADAP KELEMAHAN KONSEP AKAD DALAM KOMPILASI HUKUM EKONOMI SYARIAH
}

\author{
Abdur Rahman Adi Saputera \\ Institut Agama Islam Negeri (IAIN) Sultan Amai Gorontalo \\ Email: adisaputrabd@gmail.com \\ Mohamad Ramdan Suyitno \\ Institut Agama Islam Negeri (IAIN) Sultan Amai Gorontalo \\ Email: danisuyitno99@gmail.com \\ Muhammad Syakir Alkautsar \\ Universitas Islam Negeri (UIN) Raden Intan Lampung \\ Email: syakir.alkautsar25@gmail.com
}

\begin{abstract}
This study aims to analyze how the consequences of the weaknesses of the contract concept as stated in the KHES, and how the solutions to the weaknesses of the contract concept are. This research is a qualitative research library research (literature review) with a descriptiveanalytical approach which is strengthened by primary and secondary data sources, while the data analysis techniques used are inductive, deductive, and comparative. The results showed that the consequences of the weaknesses of the contract concept in KHES were; Different interpretations, Sharia economic disputes are not resolved, the parties are harmed and do not provide massive information. While the solution to the weakness of the concept of the contract in article 25 paragraph (2) is that the solution to the clarity of the meaning of sighat al aqd is to provide a comparison with the sighat al-aqd that is in muamalah fiqih as KHES absorption adheres to these rules. More precisely, the contract must be carried out clearly, in oral, written and/or art form, and for the harmony of the mudharabah agreement Article 232 it is customary to add the object of the contract, and the main purpose of the contract as one of the pillars in the contract, as well as adding the provisions of the qardul hasan contract to book II. in chapter XXVII, also provides limitations in article 607, while article 347 must provide clarity in detail. Keywords: Consequences, Weaknesses, Akad, KHES.
\end{abstract}

\section{A. Pendahuluan}

Masyarakat Indonesia mayoritas beragama Islam dan ada kecenderungan agama Islam menjadi agama mayoritas didunia. Dengan demikian ada kebutuhan untuk mulai menerapkan ketentuan syariah dalam berbagai sendi kehidupan masyarakat Indonesia, khususnya dalam bidang perdagangan, dan lembaga-lembaga keuangan syariah. Ekonomi dan keuangan Islam telah mengalami perkembangan yang sangat signifikan di ranah nasional maupun internasional. Dalam konteks Indonesia sendiri, kebutuhan atas ekonomi dan keuangan syariah telah memperoleh keabsahan dalam berbagai peraturan perundangan-undangan dan endrosment dari lembaga Dewan Syariah Nasional.

Pelaksanaan kegiatan ekonomi syariah di Indonesia yang di mulai sejak tahun 1991 diawali dengan pelaksanaan perbankan syariah dan merebak kebidang kegiatan ekonomi lainnya, yaitu asuransi syariah, pasar modal syariah, dan pembiayaan 
syariah. Perkembangan ini memberi pengaruh terhadap perkembangan hukum yang mengakomodasi kegiatan ekonomi syariah, khususnya dalam hal peraturan perundang-undangan. Peraturan bidang ekonomi syariah bukanlah peraturan pertama di Indonesia yang berdasar pada hukum Islam. Sejak tahun 1992 berlaku peraturan-peraturan di bidang ekonomi syariah yaitu Undang-UndangNomor 7 Tahun 1992 tentang Perbankan sebagaimana telah diubah dengan Undang-Undang Nomor. 10 Tahun. 1998 tentang perubahan atas Undang-Undang Nomor. 7 Tahun. 1992 tentang Perbankan. ${ }^{1}$

Di Indonesia konsep ekonomi syariah sudah diterapkan, dalam ranah perbankan sudah ada dalam bentuk syariah seperti Bank Syariah Mandiri, Bank Muamalat, dan lain sebagainya yang berlabelkan syariah. Penerbitan suatu produk perbankan syariah berkaitan erat dengan masalah regulasi dan sumber daya manusia. Semua yang berkaitan dengan ekonomi syariah telah di rangkum dalam Kompilasi Hukum Ekonomi Syariah (KHES). ${ }^{2}$ Belakangan, perkembangan Lembaga Keuangan Syariah (LKS) tersebut semakin pesat yang tentu akan menggambarkan banyaknya praktik hukum muamalat di kalangan umat Islam. Sedangkan hukum muamalat, secara umum belum dipraktekkan dan belum menjadi adat-istiadat umat Islam. Hukum muamalat secara kelembangaan hanya dipraktekkan melalui LKS yang secara hukum memang harus ada yang mengaturnya karena menyangkut hak-hak dan kepentingan banyak pihak dan dalam skala yang lebih besar. Sehingga perbedaan tersebut juga berimplikasi terhadap perbedaan poses positivisasinya.

Bahkan LKS yang menjadi barisan terdepan dalam penegakan hukum muamalat pun juga belum sepenuhnya menerapkannya, masih ada penyimpangan. Dengan kata lain, praktek hukum muamalat di masyarakat mungkin sudah banyak perkembangan baru yang mulai bergeser dari normativitas fikih, meskipun hal ini perlu pembuktian di lapangan. Sebagai contoh sederhana adalah keterlibatan mayoritas umat Islam dalam praktik bunga bank konvensional yang dihukumi haram oleh fatwa DSN/MUI. ${ }^{3}$

Draft KHES ini masih banyak isi yang perlu dikritisi dan disempurnakan. Seperti dalam ketentuan akad, belum menyebutkan asas-asas pokok dalam hukum akad (perjanjian), yakni asas-asas ibahah, kebebasan berakad, Konsensualisme, janji itu mengikat, keseimbangan, kemaslahatan, amanah, dan keadilan. ${ }^{4}$ Asas-asas ini sangat penting sebagai pertimbangan filosofis dalam mengembangkan reinterpretasi hukum-hukum muamalat ke dalam cakupan yang lebih luas, karena ketika hukum sudah dibakukan maka akan semakin mempersempit cakupannya. Justru dalam KHES lebih banyak menyebutkan kaidah-kaidah fighiyyah dalam satu rangkaian yang belum diklasifikasikan jenis, cakupan dan fungsinya. Justru setiap topik itu

1 Taufiq Risal, “Peningkatan Peran Perbankan Syariah Dengan Menggerakkan Sektor Riil Dalam Pembangunan," Accumulated Journal (Accounting And Management Research Edition) Vol.1, No.1, 2019, h. 36-47.

2 Abdul Ghofur, "Pengantar Ekonomi Syariah: Konsep Dasar, Paradigma, Pengembangan Ekonomi Syariah," 2017.

${ }^{3}$ Nashihul Ibad Elhas, "Kompilasi Hukum Ekonomi Syariah (KHES) Dalam Tinjauan Umum Hukum Islam," Al-Tsaman: Jurnal Ekonomi Dan Keuangan Islam, Vol.2, No.1, 2020, h 62-71.

4 Novi Ratna Sari, "Komparasi Syarat Sah Nya Perjanjian Menurut Kitab Undang-Undang Hukum Perdata Dan Hukum Islam," Jurnal Repertorium, Vol.4, No.2, 2017, h 18. 
memerlukan kaidah-kaidah tersebut sebagai landasan filosofisnya. Hal demikian itu akan semakin membuat kesimpangsiuran dalam penerapannya, sementara yang terjadi masih banyak ikhtilaf dalam hukum muamalat di kalangan ulama. Persoalan itu akan muncul ketika para pihak yang bertikai adalah para pakar dalam hukum muamalat. Masih dalam akad, KHES belum menyebutkan sub-sub topik penting dalam akad, masih terlalu global. Hal itu akan menimbulkan masalah ketika muncul perkara yang tidak ter-cover dalam KHES, sehingga penafsiran hakim yang "dipaksakan" itu justru akan menimbulkan masalah lainnya, yaitu rasa keadilan para pihak.

Pada Figh Muamalah telah menjelaskan tentang akad, Fiqh muamalahdalam arti sempit adalah Aturan-aturan Allah SWT. yang wajib ditaati yang mengatur hubungan manusia dengan manusia dalam kaitannya dengan cara memperoleh dan mengembangkan harta benda. Akad adalah perikatan ijab dan kabul yang dibenarkan syara' yang menetapkan keridhaan kedua belah pihak. Dasar hukum akad yaitu (QS Ali Imran:76). Terjemahnya: "(Bukan demikian), sebenarnya siapa yang menepati janji (yang dibuat)nya dan bertakwa, maka sesungguhnya Allah menyukai orangorang yang bertakwa."

Sebagaiman penjelasan ayat al-qur'an di atas bahwa perjanjian yang dibuat seseorang tidak memerlukan persetujuan pihak lain, baik setuju maupun tidak, tidak berpengaruh kepada janji yang dibuat oleh orang tersebut. Jika hukum itu terlalu global, maka perbedaan tak dapat terelakkan, mengingat para hakim mempunyai paradigma dan perspektif yang berbeda-beda. Sebagai contoh lain adalah dalam akad qard disebutkan bahwa biaya administrasi dalam akad qard dibebankan kepada nasabah, dengan tanpa diberi batasan. Hal itu akanmenimbulkan masalah ketika kreditur menafsirkan secara berlebihan yang terlalu membebani debitur. Dan masih banyak lagi yang perlu disempurnakan. ${ }^{5}$ Dalam hal ini peneliti ingin menganalisa tentang baimana konsekuensi atas kelemahan konsep akad yang tertuang dalam KHES, dan bagaimana solusi atas kelemahan konsep akad pada KHES.

\section{B. Pembahasan}

\section{B.1. Sejarah Singkat Kompilasi Hukum Ekonomi Syariah (KHES)}

Sejarah dibentuknya Kompilasi Hukum Ekonomi Syariah (KHES) tidak dapat terlepas dari amanat Pasal 49 UU No. 3 Tahun 2006 tentang Perubahan Atas UU No. 7 Tahun 1989 tentang Peradilan Agama. Implikasi dari Undang-undang yang mengatur tentang Ekonomi Islam, pemerintah dan Istitusi pengadilan pada saat itu harus mengambil tindakan kongkrit agar ada kewenangan absolut apabila terjadi sengketa, maka lahirlah Undang-Undang No. 3 Tahun 2006 perubahan dari UndangUndang No. 7 Tahun 1989 tentang Peradilan Agama. ${ }^{6}$

Atas dasar pasal tersebut Hakim Peradilan Agama Berhak menyeselesaikan sengketa dalam bidang Ekonomi Syariah.Mahkamah Agung kemudian membentuk

5 Abdul Mughits, “Kompilasi Hukum Ekonomi Syari’ah (KHES) Dalam Tinjauan Hukum Islam," Al-Mawarid Journal of Islamic Law, Vol.18, No.1, 2008, h. 34.

${ }^{6}$ husni Kamal, "Penyelesaian Sengketa Ekonomi Syariah Pasca Putusan Mk No. 93/Puu-X/2012 (Analisis Putusan Pengadilan Agama Cilegon No. 411/Pdt. G/2013/PA. Clg)" (Universitas Islam Negeri" Sultan Maulana Hasanuddin" Banten, 2018). 
suatu Tim Penyusun KHES berdasarkan Surat Keputusan Mahkamh Agung Nomor: KMA/097/SK/X/2006 yang diketuai oleh Prof. Dr. Abdul Manan, yang nantinya akan dilaporkan ke Ketua Mahkamah Agung. Langkah awal dilakukan oleh Tim Penyusun adalah menyesuaikan pola pikir (united legal opinion) dengan melibatkan berbagai kalangan termasuk Badan Arbitrase Syariah Nasional. Langkah berikutnya adalah mencari format yang ideal (united legal frame work) yang banyakmendengar paparan petinggi BI. Hingga pada langkah terakhir Tim banyak merujuk pada studi pustaka dan perbandingan dengan negara lain.Pada draft awal KHES terdapat 1040 pasal dalam 5 bab, sedangkan pada draft terakhir menjadi 849 pasal dalam 4 bab 6 Pada penyusunan tersebut, diakui bahwa Tim dapat menyusun draft tersebut setelah merujuk pada kitab Majallah Al-Ahkam (kitab undang-undang perdata Islam yang disusun oleh Pemerintah Turki Usmani pada tahun 1800-an) terdiri dari 1851 pasal. Banyak yang berpendapat dari para ahli Hukum Islam, Bahwa secara praktik kitab rujukan dalam pembuatan KHES ini telah terlampau mengalami ketertinggalan dalam segi perkembangan hukum, sehingga belum mencakup dan belum sesuai dengan kebutuhan payung hukum untuk perkembangan ekonomi Islam di Indonesia. ${ }^{7}$

Untuk menyempurnakan draft awal tersebut, materi baru dimasukan diambil dari kitab-kitab fikih kontemporer dan hasil kajian ilmiah yang diselengarakan pusat kajian ekonomi Islam internasional. Pembahasan KHES dalam berbagai catatan disebutkan tidak membutuhkan waktu yang lama, kurang lebih sekitar 1 tahun (2 tahun sejak tim dibentuk oleh Mahkamah Agung) hingga KHES ditetapkan melalui PERMA No. 02 Tahun 2008 tanggal 10 September 2008. 8

KHES terdiri dari atas 796 pada awal pembuatan dan kemudian di revisi menjadi 790 pasal dan 5 bab. Berikut 5 bab dalam KHES yaitu: kecakapan hukum, pengampuan dan keterpaksaan, harta, akad, zakat dan hibah. Kemudian pada draft akhir menjadi 4 bab, di mana sistematika dalam Kompilasi Hukum Ekonomi Syariah (KHES) tersebut, terdiri atas: Pertama, Buku I tentang Subjek Hukum dan Amwal. Kedua, Buku II tentang Akad. Ketiga, Buku III Zakat dan Hibah. Keempat, Buku IV tentang Akuntansi syariah. KHES terdiri dari 790 pasal. Untuk mempermudah dalam mengetahui isi draft dalam KHES peneliti membuat tabel sebagaiamana berikut:

\section{Tabel 1. Subtansi KHES}

\begin{tabular}{|c|l|c|c|}
\hline No. & \multicolumn{1}{|c|}{ Buku } & BAB & Jumlah Pasal \\
\hline 1. & Buku I Subjek Hukum dan Amwal & 3 & 19 \\
\hline 2. & Buku II Tentang Akad & 29 & 648 \\
\hline 3. & Buku III Zakat dan Hibah & 4 & 60 \\
\hline 4. & Buku IV tentang Akuntansi Syariah & 7 & 63 \\
\hline 5. & Jumlah & 44 & 790 \\
\hline
\end{tabular}

7 Mughits, “Kompilasi Hukum Ekonomi Syari'ah (KHES) Dalam Tinjauan Hukum Islam."

8 Ifa Lathifa Fitriani, "Kompilasi Hukum Ekonomi Syariah Dalam Pemaknaan Hukum Islam Dan Sistem Hukum Positif Di Indonesia," Supremasi Hukum: Jurnal Kajian Ilmu Hukum Vol.5, No.1, 2020, h. 81 . 
Dari hasil tabel diatas dalam draft KHES terdapat 44 Bab, dan 790 pasal. Dimana dalam Buku II tentang akad berjumlah 648 pasal maka yang paling banyak untuk pembahasan mengenai draft dalam KHES yaitu tentang akad. Jika dilihat dari prosentasi Buku I Subjek Hukum dan Amwal sebanyak 2\% sedangkan yang paling banyak banyak adalah Buku II Asas Akad Dan Rukun Akad, Aib, dan Penafsiran Akad Serta Jenis-Jenis Akad sebanyak 82\%, adapun Buku III Zakat dan Hibah sebanyak 8\%, dan Buku IV Akuntansi Syariah sebanyak 8\%. Maka untuk Buku III dan IV dalam KHES ini berimbang. Banyak materi pada Buku II menunjukan bahwa materi KHES didominasi oleh pembahasan jenis-jenis akad yang diaplikasikan pada berbagai tranksaksi keuangan syariah.

\section{B.2. Ketetapan Kompilasi Hukum Ekonomi Syariah pada Bab II Pasal 21 Tentang Asas-asas Akad}

Pada buku II KHES ini berbicara mengenai akad dan yang paling banyak subtansi dari KHES ini adalah akad sebagaiman yang telah di analisa oleh peneleti. Di dalam subtansi akad ini ada beberapa istilah akad yang ada pada KHES dan dijelaskan secara pada Bab II Pasal 21 tentang asas akad. Istilah asas berasal dari bahasa arab yang berarti dasar atau landasan. Sedangkan secara termenologi, yang dimaksud dengan asas ialah nilai-nilai dasar yang menjadi bahan npertimbangan untuk melakukan perbuatan. Karena nilai dasar itu sangat berpengaruh terhadap perbuatan atau perilaku manusia secara lahiriyah (akhlaq), maka nilai-nilai dasar tersebut harus mengandung unsur-unsur kebenaran hakiki. ${ }^{9}$

Akad adalah kesepakatan dalam suatu perjanjian antara dua belah pihak atau lebih untuk melakukakan dan/atau tidak melakukan perbuatan hukum tertentu. Berdasarkan Kompilasi Hukum Ekonomi Syariah (KHES) akad dilakukan berdasarkan 13 asas antara lain; asas ikhtiya'ri (sukarela); asas amanah(menepati janji); asas ikhtiya'ti (kehati-hatian); asas Luzum (tidak berubah); asas saling menguntungkan; asas taswiyah (kesetaraan); asas transparaansi; asas kemampuan; asas taysi'r (kemudahan); asas iktikad baik; sebab yang halal; asas al-Hurriyah (kebebasan berkontrak dan asas al-kita'bah (tertulis). Asas-asas inilah yang perlu untuk diperhatikan dalam menjalankan suatu akad agar terhindar dari konflik-konflikyang mungkin terjadi dalam proses penjalanan akad tersebut setelah nantinya disepakati. Sebab sah dan tidaknya sah suatu akad ini harus memegang atau mendasari asas akad ini sebagaimana yang tertera pada Buku II Bab II KHES.Dalam penelitian ini peneliti membahas 13 asas akad yang ada dalam (KHES), antara lain yaitu: (1) Asas Ikhtiyari (Sukarela), (2) Asas Amanah (Menepati Janji), (3) Asas Ihktiyati (Kehati-hatian), (4) Asas Luzum (Tidak berubah), (5) Asas Saling Menguntungkan, (6) Asas Taswiyah (Kesetaraan), (7) Asas Transparansi , (8) Asas Taysir (Kemudahan), (9) Asas I'tikad Baik, (10) Asas Sebab yang Halal, dan Asas al-hurriyah (Kebebasan Berkontrak). ${ }^{10}$

9 Bagus Ahmadi, “Akad Bay', Ijarah Dan Wadi'ah Perspektif Kompilasi Hukum Ekonomi Syariah (KHES)," Epistemé: Jurnal Pengembangan Ilmu Keislaman, Vol.7, No.2, 2012, h. 36.

10 Nugraha Pranadita, "Akad-Akad Dalam Kompilasi Hukum Ekonomi Syariah (KHES) Dan Implementasinya Pada Sebuah Warung," Jurnal Hukum, Vol.32, No.2, 2016, h. 84. 


\section{B.3. Ketetapan Kompilasi Hukum Ekonomi Syariah pada Bab III Tentang Rukun Akad, Syarat Akad, Kategori Hukum Akad, Aip Kesepakatan, dan Ingkar Janji \\ B.3.1. Rukun dan Syarat akad}

Pembahasan mengenai rukun akad dalam kitab kompilasi hukum ekonomi syariah (KHES) diatur dalam Bab III bagian pertama pasal 22 tentang rukun dan syarat akad. Adapun rukun akad menurut KHES itu sendiri terdiri atas, 11

1. Pihak yang berakad: dimana syarat dari para pihak itu sendiri diatur dalam pasal 23. Pertama, pihak-pihak yang berakad adalah orang perseorangan, kelompok orang, persekutuan, atau badan usaha; dan kedua, orang yang berakad harus cakap hukum, berakal, dan tamyis.

2. Objek akad: untuk syarat dari objek akad yang diatur dalam KHES terdiri dari dua syarat yang keduanya diatur dalam pasal 24. Pertama, objek akad adalah amwal atau jasa yang dihalalkan yang dibutuhkan masing-masing pihak; dan kedua, objek akad harus suci, bermanfaat, milik sempurna, dan dapat diserahterimakan.

3. Tujuan pokok akad dan untuk tujuan dari akad itu sendiri adalah untuk memenuhi kebutuhan hidup dan pengembangan usaha masing-masing pihak yang mengadakan akad. Hal ini berdasarkan syarat yang mengaturnya dalam KHES pasal 25.

4. Kesepakatan. kesepakatan disini sering dikenal dengan ijab kabul atau sighat akad. Syarat ini juga diatur dalam KHES paasal 25 dimana sighat akad dapat dilakukan dengan jelas, baik secara lisan, tulisan ataupun perbuataan

Itulah beberapa rukun dan syarat yang berada dalam KHES yang merupakan pedoman untuk mengetahui apakah akad ini batal atau tidak. Sebab rukun dan syarat ini lah yang menentukan batal dan tidaknya suatu akad.

\section{Kesepakatan (Ijab dan Qabul)}

Menurut pasal 29 kompilasi hukum ekonomi syariah akad yang sah adalah akad yang disepakati dalam perjanjian, tidak mengandung unsur ghalat atau khilafi2 dilakukan dibawah ikrah atau paksaan ${ }^{13}$ taghrir atau tipuan ${ }^{14}$, dan ghubn atau penyamaran. ${ }^{15}$ Setiap kesepakatan dalam bisnis harulah jelas harus diketahui oleh para pihak yang berakad agar tidak menimbulkan perselisihan diantara mereka. Kesepakatan para pihak dalam hukum perjanjian syariah yang ditulis oleh Samsul Anwar dikenal dengan pernyataan kehendak. Dimana pernyataan kehendak itu sendiri lajim disigat akad (sighat al-aqd) yang terdiri dari ijab dan qabul. Ijab dan qabul inilah yang mempresentasikan perijinan

\footnotetext{
11 Elhas, "Kompilasi Hukum Ekonomi Syariah (KHES) Dalam Tinjauan Umum Hukum Islam."

12 Kekhilafan Tidak Mengakibatkan Batalnya Suatu Akad Kecuali Kekhilafan Itu Terjadi Mengenai Hakikat Yang Menjadi Pokok Perjanjian. Lihat Pasal 30 Kompilasi Hukum Ekonomi Syariah

13 Paksaan Adalah Mendorong Seseorang Melakukan Sesuatu Yang Tidak Diridhoinya Dan Tidak Merupakan Pilihan Bebasnya. Lihat Pasal 31 Kompilasi Hukum Ekonomi Syariah.

14 Penipuan Adalah Mempengaruhi Pihak Lain Dengan Tipu Daya Untuk Membentuk Akad, Berdasarkan Bahwa Akad Untuk Ke-Maslahatan-Nya, Tetapi Dalam Kenyataan Sebaliknya. Lihat Pasal 33 Kompilasi Hukum Ekonomi Syariah.

15 Penyamaran Adalah Keadaaan Dimana Tidak Ada Kesetaraan Antara Prestasi Dengan Imbalan Prestasi Dalam Suatu Akad. Lihat Pasal 35 Kompilasi Hukum Ekonomi Syariah.
} 
(ridha, persetujuan). Dalam bahasa lain ijab dan qabul disebut juga sebagai penawaran dan penerimaaan. Penawaran dan penerimaaan oleh pembuat; kematian dari suatu pihak atau kerugian kapasitas untuk masuk kedalam kontrak: berakhirnya majelis, seperti periode kontrak, tanpa pengambilan kesimpulan kontrak; penerimaan penurunan subjek; serta kehilangan waktu yang ditetapkan untuk penerimaan. Ini merupakan persyaratan hukum islam bahwa penerimaan harus dikonfirmasikan untuk penawaran dalam keseluruhan secara detail dan hal tersebut harus diterima dalam pertemuan yang sama begitu juga sebaliknya, penawaran juga harus konsisten atau tidak berubah dan dikonfirmasikan secara detail agar pihak penerima dapat mempertimbangakan segala hal yang ada dalam penawaran tersebut. ${ }^{16}$

\section{Aib Kesepakatan}

Berdasarkan syarat sahnya suatu akad atau perjanjian tersebut diatas, khususnya syarat kesepakatan yang merupakan penentu terjadinya atau lahirnya suatu perjanjian, yang berarti bahwa tidak adanya kesepakatan para pihak, maka tidak terjadi kontrak. Akad tetapi walaupun terjadi kesepakatan para pihak yang melahirkan perjanjian, namun terdapaat kemungkinan bahwa kesepakataan yang telah dicapai tersebut mengalami kecacatan atau bisa disebut cacat kehendak. Sehingga memungkinkan perjanjian tersebut dimintakan pembatalan oleh pihak yang merasa dirugikan oleh perjanjian tersebut. Kompilasi Hukum Ekonomi Syariah, cacat kehendak dikenal dengan aip kesepakatan yang diatur dalam pasal 29 sebagaimana yang telah dijelaskan sebelumnya nahwa akad yang sah adalah akad yang disepakati dalam perjanjian, tidak mengandung unsur ghalat atau khilaf, dilakukan dibawah $i k r a h$ atau paksaan, taghrir atau tipuan, dan ghubn atau penyamaran. Namun menurut Ahmad Miru dalam hukum kontrak bernuansa islam menambahkan adanya penyalahgunaan keadaan sebagai salah satu dari bagian yang menimbulkan cacat kehendak menurutnya, penyalahgunaan keadaan terjadi jika pihak yang memiliki posisi yang kuat (posisi tawarannya) dari psikologi menyalahgunakan keadaan sehingga pihak lemah menyepakati hal-hal yang memberatkan baginya. ${ }^{17}$

\section{Hukum Akad}

Pada pasal 27 kompilasi hukum ekonomi syariah dijelaskan bahwa hukum akad terbagi dalam tiga kategori yaitu; a. Akad yang sah; b. Akad yang fasad/ dapat dibatalkan. c. Akad yang batal demi hukum. Pertama, akad yang sah. Akad yang sah menurut kompilasi hukum ekonomi syariah adalah akad yang terpenuhi rukun dan syarat-syaratnya suatu perjanjian (akad) tidak cukup hanya secara faktual, tetapi keberadaannya juga harus sah secara syar'i (Yuridis) agar perjanjian (akad) tersebut dapat melahirkan akibat-akibat hukum yang

\footnotetext{
16 Mutiara Citra, Rika Lestari, and Rahmad Hendra, “Tinjauan Yuridis Terhadap Kawin Kontrak Dalam Perspektif Hukum Perjanjian Dan Hukum Islam”, Riau University, 2016, h. 34.

17 Rahmani Timorita Yulianti, “Asas-Asas Perjanjian (Akad) Dalam Hukum Kontrak Syari'ah," Jurnal Fakultas Hukum UII, Vol.2, No.1, 2008, h. 107.
} 
dikehendaki oleh para pihak yang membuatnya. Menurut Syamsul Anwar dalam Hukum Perjanjian Syariah menegaskan bahwa suatu akad menjadi sah apabila rukun dan syaratnya terpenuhi dan tidak sah apabila rukun dan syaratnya tidak terpenuhi.

Kedua, akad yang fasad. Akad yang fasad menurut Kompilasi Hukum Ekonomi Syariah adalah akad yang terpenuhi rukun dan syart-syaratnya tetap terdapat segi atau hal lain yang merusak akad tersebut karena pertimbangan maslahat.

Ketiga, akad yang batal. akad yang batal menuirut Kompilasi Hukum Ekonomi Syariah adalah akad yang kurang rukun dan/atau syarat-syaratnya. Akad batal adalah akad yang tidak dibenarkan secara syarah ditinjau dari rukun-rukunnya maupun pelaksaannya, dan ia dipandang tidak pernah terjadi menurut hukum, meskipun secara material pernah terjadi, oleh karenanya tidak mempunyai akibat hukum sama sekali. hal serupa juga di sampaikan oleh Mardani dalam Hukum Perikatan Syariah di Indonesia menyatakan bahwa akad yang tidak sah atau tidak sahih (void contract) adalah akad yang tidak memenuhi unsur dan syaratny. Dengan demikian, berdampak hukum tidak sah. ${ }^{18}$

\section{Ingkar Janji (Wanprestasi)}

Berbagai hukum perjanjian, apabila suatu perjanjian (akad) telah memenuhi semua syarat-syaratnya, dan menurut hukum perjanjian Islam apabila telah memenuhi telah memenuhi rukun dan syarat-syaratnya perjanjian tersebut mengikat dan wajib dipenuhi serta berlaku sebagai hukum. Dengan kata lain, perjanjian itu menimbulakn akibat hukum yang wajib dipenuhi oleh pihak-pihak terkait. Ahmad Miru menegaskan dalam Hukum Kontrak Bernuansa Islam, bahwa pada tahap pelaksanaan perjanjian, jika salah satu pihak atau kedua belah pihak tidak melaksanakan kewajiban sesuai dengan perjanjian yang telah dibuatnya, maka itulah yang disebut wanprestasi. ${ }^{19}$ Menurut Kompilasi Hukum Ekonomi Syariah dalam pasal 36 dijelaskan bahwa para pihak dapat dianggap ingkar janji apabila karena kesalahannya; (1) Tidak melaksanakan apa yang dijanjikan untuk melakukannya; (2) Melaksanakan apa yang dijanjiakan tetapi tidak sebagaimana dijanjikan; (3) Melakukan apa yang dijanjikan tetapi terlambat; dan (4) Melakukan sesuatu yang menurut perjanjian tidak boleh dilakukan.

\section{B.4. Konsekuensi Kelemahan Konsep Akad Dalam Kompilasi Hukum Ekonomi Syariah (KHES)}

KHES tentu saja bukan kitab suci yang tidak bisa diubah-ubah, karena konsep KHES seiringin berkembangnya kehidupan sosial yang dimana yaitu mengenai permasalahan ekonomi, tentunya dapat mengubah hukum itu sendiri menurut

18 Johar Arifin, "Substansi Akad Dalam Transaksi Syariah," Al-Amwal: Jurnal Ekonomi Dan Perbankan Syari'ah, Vol.6, No.1, 2016, h. 63.

19 M.Ichsanuddin, "Tinjauan Hukum Islam Terhadap Wanprestasi Dalam Hukum Perdata”, IAIN Sunan Ampel Surabaya, 1988, h. 2. 
kebiasaan banyak orang dalam hal ini fiqih muamalah merupakan hukum islam yang memuat permasalahan manusia dan manusia. Alangkah buruknya jika hukum itu tidak mengikuti zaman sebab akan ada ketimpangan dikehidupan. Akan ada tindakan semena-mena yang dilakukan oleh pihak-pihak yang punya kepentingan, alhasil sebagianya akan merasa dirugikan. Maka dalam hal ini peneliti ingin merekomendasikan kosekuensi terhadap produk hukum islam yaitu KHES dimana yang bergerak dalam ekonomi islam, sebagaimana kita ketahui bahwa ekonomi Islam sudah merebak di Indonesia dengan adanya Lembaga Keuangan Syariah (LKS) di indonesia. Apalagi mayoritas penduduk agama di Indonesia adalah Islam Tanggal 10 september 2008 Ketua Mahkamah Agung telah menetapkan peraturan Mahkamah Agung RI No. 02 tahun 2008 tentang KHES. KHES merupakan perangkat peraturan yang menjadi lampiran dan merupakan bagian yang tidak terpisahkan dari peraturan Mahkamah Agung RI No. 2 Tahun 2008. Dalam Hal ini KHES masih terdapat kelemahan didalam Subtansi hukumnya. Seperti dalam kelemahan konsep akad yang ada dalam KHES ini, tentunya akan mendapatkan konsekuensi dengan apa yang terdapat pada kelemahan KHES ini, peneliti akan menyebutkan apa saja yang akan diakibatkan dari kelemahan konsep akad KHES dengan melihat dari penerapannya akad yang ada di dalam KHES yaitu sebagai berikut:

1. Rukun dan Syarat Akad pada Pasal 25 ayat (2)

Sebagaimana penjelasan rukun dan syarat akad pada Bab II Kompilasi Hukum Ekonomi Syariah (KHES) ini yaitu sebagai berikut:20

Pasal 22

rukun akad terdiri atas:

a. Pihak-pihak yang berakad,

b. Objek akad,

c. Tujuan pokok akad,

d. Kesepakatan.

Pasal 23

a. Pihak-pihak yang berakad adalah orang perseorang, kelompok orang, persekutuan, atau badan usaha.

b. Orang yang berakad harus cakap hukum, berakal, dan tamyiz.

\section{Pasal 24}

a. Objek akad adalah amwal atau jasa yang dihalalkan yang dibuthkan oleh masing-masing pihak.

b. Objek akad harus suci, bermanfaat, milik sempurna, dan dapat diserahterimakan.

\section{Pasal 25}

a. Bertujuan untuk memenuhi kebutuhan hidup dan pengembangan usaha masing-masing pihak yang mengadkan akad.

b. Sighat akad dapat dilakukan dengann jelas, baik secara lisan, tulisan, dan/atau perbuatan.

20 Pasal 22-25 Kompilasi Hukum Ekonomi Syariah. 
Pada pasal 25 ayat (2) diatas yaitu mengenai sighat akad terdapat bahasa yang kurang tepat untuk penjelasan pasal 25 ayat (2) bahwa pada kata "dapat" dalam teks ini tidak bersifat mengharuskan (wajib; imperatif), padahal bentuk akad pada dasarnya harus jelas, tegas dan bahkan lugas. itulah sebabnya para ahli hukum Islam (fukaha) sampai besusah-susah payah merumuskan redaksi akad (sighat al'aqd) dengan lafal-lafal yang tidak boleh ambigu. Dalam fiqih muamalah yaitu mengenai sighat al'aqd, Shighat al'aqd harus jelas pengertiannya. Kata-kata dalam ijab qabul harus jelas dan tidak memiliki banyak pengertian.misalnya seorang berkata "aku serahkan barang ini," kalimat tersebut masih kurang jelas sehingga masih menimbulkan pertanyaan; apakah benda tersebut diserahkan sebagai pemberian, penjualan, ataupun titipan. Kalimat yang lengkapnya ialah "aku serahkan benda ini kepadamu sebagai hadiah atau sebagai pemberian". 21

Dalam bahasa hukum di jelaskan bahwa suatu bahasa aturan dan peraturan yang bertujuan untuk mewujudkan ketertiban dan keadilan, untukmempertahankan kepentingan umum dan kepentingan pribadi di dalam masyarakat. Namun dikarenakan bahasa hukum adalah bagian dari bahasa indonesia yang moderen, maka dalam penggunaannya harus tetap, terang, monosemantik (hubungan antara ungkapan dan makna yang tetap dan tegas), dan memenuhi syarat estetika bahasa indonesia. Imam ahmad mengatakan bahwa akad jual beli tidak sah jika menggunakan kiasan, karena orang yang diajak bicara tidak tahu apakah dia diajak bicara tentang jual beli atau lainnya. ${ }^{22}$ Beberapa akad yang dimaksudkan dalam KHES pada penelitian ini diantaranya:

\section{B.4.1. Akad Mudharabah}

Mudharabah berasal dari kata al-dharb yang berarti memukul atau berjalan. Kemudian disebut adhdharby fil ardhi yaitu bepergian untuk urusan dagang. Disebut juga qiradh yang berasal dari kata alqardhu yang berarti potongan, karena pemilik memotong sebagian hartanya untuk diperdagangkan dan memperoleh sebagian keuntungan mudharabah adalah akad perjanjian antara dua belah pihak atau lebih untuk melakukan kerja sama usaha. Satu pihak akan menetapkan modal 100\% yang disebut dengan shahibul maal, dan pihak lain-nya sebagai pengelola usaha, disebut mudharib. Bagi hasil dari usaha yang dikerjasamakan dihitung sesuai dengan nisbah yang disepakati antara pihak-pihak yang bekerja sama. Fatwa Dewan Syariah Nasional mendefinisikan mudharabah sebagai berikut: Mudharabah adalah akad kerja sama dalam suatu usaha antara dua pihak dimana pihak pertama (malik, shahib al-mal, LKS) menyediakan seluruh modal, sedang pihak kedua (amil, mudharib, nasabah) bertindak selaku pengelola, dan keuntungan usaha dibagi antara mereka sesuai kesepakatan yang dituangkan dalam kontrak. Akad mudharabah yang pada

21 Rahayu Ningsih Eka Putri, “Penggunaan Kompilasi Hukum Ekonomi Syariah (Khes) Dalam Putusan Perkara Perlawanan Eksekusi Lelang Hak Tanggungan Pembiayaan Fasilitas Murabahah (Studi Kasus Putusan Nomor: 1301/Pdt. G/2019/PA. JP)" (IAIN Purwokerto, 2020).

22 Edhy Rustan, “Analisis Penggunaan Bahasa Indonesia Laras Hukum Pada Putusan Perkara Ekonomi Syariah Pengadilan Agama Makassar", Center for Open Science, 2016, h. 35. 
KHES ini sebagaimana yang tertuang dalam pasal 232 hanya terdiri tiga unsur/rukun saja. Pasal 232 sebagaiman mengenai rukun kerja sama dalam modal dan usaha yaitu: (1) Shahib al-mal/Pemilik Modal; (2) Mudharib/Pelaku Usaha; dan (3) Akad.23

Sedangkan dalam pasal 20 KHES akad adalah kesepakatan dalam suatu perjanjian antara dua belah pihak atau lebih untuk melakukan dan atau tidak melakukan perbuatan hukum tertentu. Sebagaimana pembuatan akad dalam KHES adalah positivisasi dari Akad yang ada dalam fiqh muamalah. Dalam hal ini terdapat rukun yang harus di jalankan dalam akad mudharabah ini sebagaimana dalam pasal 22 KHES mengenai rukun akad dalam KHES yaitu: (1) Pihak yang Berakad; (2) Objek Akad; (3) Tujuan Pokok Akad; dan (4) Kesepakatan. Semua rukun akad tersebut adalah merupakan rukun dasar akad yang harus terdapat dalam setiap jenis akad dalam KHES, tidak terkecuali dalam akad mudharabah, namun jika kita melihat pada rukun mudharabah dalam KHES ini hanya terdiri dari tiga unsur yang tertuang dalam pasal 232 yaitu Shahib al-mal/pemilik modal, Mudharib/pelaku usaha, dan akad. maka tentu ada rukun yang belum tertuang dalam pasal 232 yaitu objek akad. ${ }^{24}$

Sebagaimana dalam fiqih muamalah objek akad dinamakan ahal al-'AqdI yaitu menentukan objek akad. Pengertian objek akad adalah sesuatu yang oleh syarace dijadikan objek dan dikenakan pada akibat hukum yang ditimbulkan. Dari pengertian yang telah dijelaskan, pada dasarnya objek akad dapat terbagi menjadi dua, yaitu harta benda dan manfaat perbuatan itu sendiri. Menurut para fuqaha, agar sesuatu itu dapat dijadikan sebagai objek akad yang merupakan bagian rukun akad maka harus memenuhi persyaratan sebagai berikut:

1. Sesuatu yang menjadi akad harus sesuai dengan prinsip syariah (masyru). Karenanya apabila objek akad sesuai dengan prinsip-prinsip syariah, keberadaan objek akan akan menjadi kemaslahan manusia.

2. Adanya kejelasan objek akad sehingga dapat diserahterimakan. Hal ini untuk menghindari perbuatan gharar (penipuan) dan ketidak jelasan objek akad yang nantinya akan menjadi penghalang serah terima kepemilikan.

3. Syarat kepemilikan sempurna terhadap objek akad. Pada dasarnya islam melarang transaksi terdapat objek akad yang bukan menjadi kewenangannya. Mengadakan sesuatu tanpa sepengetahuan pemiliknya dinamakan dengan akad fudhuli

Peneliti juga berpendapat bahwa rukun mudharabah tidak terbatas pada ijab dan qabul saja, tetapi perlu juga tambahan adanya dua pihak, keja/usaha, laba/kuntungan dan modal, dimana ketiga unsur terakhir merupakan unsur terakhir yang masuk dalam kategori objek akad yang notabene adalah rukun dasar akad yang kedua sebagaimana dimaksud pada pasal 22 KHES. Objek akad dalam akad mudharabah yaitu usaha, modal, keuntungan. Dengan tidak di camtumkannya objek akad dalam rukun mudharabah, maka bisa di simpulkan rukun akad yang terdapat dalam akad Mudharabah KHES tidak singkron dengan rukun dasar akad.

23 Popon Srisusilawati and Nanik Eprianti, "Penerapan Prinsip Keadilan Dalam Akad Mudharabah Di Lembaga Keuangan Syariah," Law and Justice, Vol.2, No.1, 2017, h. 12-23.

24 Any Widayatsari, "Akad Wadiah Dan Mudharabah Dalam Penghimpunan Dana Pihak Ketiga Bank Syariah," Economic: Journal of Economic and Islamic Law, Vol.3, No.1, 2013, h. 21. 


\section{B.4.2. Akad Qard}

Secara bahasa qard berarti al-aqat yang artinya potongan karena harta orang yang memberikan pinjaman (kreditur) diberikan kepada orang yang meminjam (debitur). Secara bahasa qard berarti al-aqat yang artinya potongan karena harta orang yang memberikan pinjaman (kreditur) diberikan kepada orang yang meminjam (debitur). Secara istilah, menurut Hanafiah qard adalah harta yang memiliki kesepakatan yang diberikan untuk ditagih kembali atau dengan kata lain, suatu transaksi yang dimaksud untuk memberikan harta yang memiliki kesepadanan kepada orang lain untuk dikembalikan yang sepadan dengan itu. Menurut KHES qard pada pasal 20 ayat (36) adalah penyedian dana atau tagihan antara lembaga keuangan Syariah dengan pihak peminjam yang mewajibkan pihak peminjam untuk melakukan pembayaran secara tunai atau cicilan dalam waktu tertentu. Menurut Fatwa DSN MUI Al-Qardhadalah pinjaman yang diberikan kepada nasabah (muqtaridh) yang memerlukan. ${ }^{25}$

Dalam akad qard ini terdiri dari dua macam qard yaitu al-qard dan qardul hasan. Sedangkan qardul hasan adalah suatu interst free financing. Kata hasan berasal dari bahasa arab yaitu ihsan yang artinya kebaikan kepada orang lain. Qardul hasan yaitu jenis pinjaman yang diberikan kepada yang sangat memerlukan untuk jangka waktu tertentu tanpa harus membayar keuntungan. Penerimanaan Qardul hasanhanya berkewajiban melunasi jumlah pinjaman pokok tanpa di haruskan memberikan tambahan apapapun. Namun pemberi pinjaman boleh saja atas kebijakannya sendiri membayar lebih dari uang yang dipinjamnya sebagai tanda terimaksih kepada pemberi pinjaman. Tetapi hal tersebut di diperrjanjikan sebelumnnya dimuka. Landasan hukum qardul hasan ini adalah al-Quran dan al-Hadis, dalil berlakunya Qardul hasan ini terdapat dalam al-Quran surat al-Hadiid ayat 11 yang artinya;" siapakah kamu yang mau meminjamkan kepada Allah pinjaman yang baik, Allah akan melipatgandakan (balasan) pinjaman itu untuknya dan dia akan memperoleh pahala yang

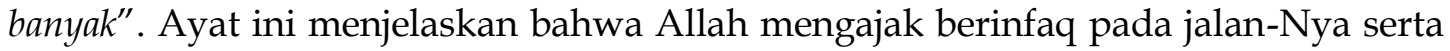
menjadikan kepada orang yang mau melakukannya dengan harapan mendapat pahala, maka tuhannya akan melipatgandakan pahala infaq itu dengan memberikan satu kebajikan menjadi tujuh ratus kali dan memperoleh balasan yang tidak terhingga di dalam surga.

Dari definisi di atas peneliti menyimpulkan pengertian qard adalah memberikan harta kepada peminjam untuk dimanfaatkan dan dikembalikan sesusai kesepakatan dilain waktu. Menurut peneliti Dalam akad qard yang terdapat pada KHES ini masih mengalami kelamahan sebab pada buku II di bab XXVII pasal 612-617 disebutkan hanya mengenai akad al-qardh dan untuk akad qardul hasantidak disebutkan secara khusus. Dalam akad qard ini pada pasal 607 KHES menyebutkan:" Biaya administrasi dibebankan kepada nasabah." Pada pasal ini KHES tidak memberi batasan mengenai akad pada pasal 607 KHES karena akan memicu kesan riba atau keuntungan yang lebih dari hal biaya admistrasi ini. Namun untuk konsep riba tidak dicantumkan dalam KHES. dalam asas saling menguntungkan sebagaimana pasal 21 yaitu

${ }^{25}$ Andy Triyawan, “Konsep Qard Dan Rahnmenurut Fiqhalmadzhahib," Ijtihad: Jurnal Hukum Dan Ekonomi Islam Vol.8, No.1, 2014, h. 68. 
menyebutkan setiap akad dilakukan untuk memenuhi kepentingan para pihak sehingga tercegah dari praktik manipulasi dan merugikan salah satu pihak. Maka untuk akad qardini tidak menerapkan asas saling menguntungkan sebagaimana penjelasan mengenai asas akad dalam KHES. ${ }^{26}$

Menurut bahasa riba penambahan, pertumbuhan, kenaikan dan ketinggian. Sebagaimana di jelaskan dalam al-Quran surat An-Nahl ayat 92 yang artinya;" disebab adanya satu golongan yang lebih banyak jumlahnyadari golongan yang lain". Dari penjelasan ayat ini lebih banyak jumlah dan hartanya. Sedangkan menurut terminologi syara, riba berarti akad untuk satu ganti khusus tanpa diketahui perbandingannya dalam penilaian syaruat ketika berakad atau bersama dengan mengakhirkan kedua ganti atau salah satunya. Adapun sebab haramnya riba karena riba menghendaki pengembalian harta orang lain dengan tidak ada imbangannya, seperti seorang menukarkan uang kertas Rp10.000,00 dengan uang recehan senilai Rp9.950,00 maka uang senilai Rp50,00 tidak ada imbangannya, maka uang senilai Rp50,00 adalah riba.

Dalam Hal ini KHES masih terdapat kelemahan didalam Subtansi hukumnya. tentunya akan mendapatkan kosekuensi dengan apa yang terdapat pada kelemahan KHES ini, peneliti akan menyebutkan kosekuensi apa saja yang akan diakibatkan dari kelemahan konsep akad ini, yaitu sebagai berikut:

1. Penafsiran yang berbeda-beda

Mengingat bahwa KHES merupakan hukum positif yang telah ditetapkan melalui PERMA No. 2 Tahun 2008 sebagai hukum materil pada lingkungan Pengadilan Agama yang melalui Undang-undang No. 3 Tahun 2006 telah diberikan kewenangan untuk mengadili perkara sengketa ekonomi syariah. Contohhnya Pada pasal 25 ayat (2) diatas yaitu mengenai sighat akad terdapat bahasa yang kurang tepat untuk penjelasan pasal 25 ayat (2) bahwa pada kata "dapat" dalam teks ini tidak bersifat mengharuskan (wajib; imperatif), padahal bentuk akad pada dasarnya harus jelas, tegas dan bahkan lugas. Dalam bahasa hukum di jelaskan bahwa suatu bahasa aturan dan peraturan yang bertujuan untuk mewujudkan ketertiban dan keadilan, untuk mempertahankan kepentingan umum dan kepentingan pribadi di dalam masyarakat. Namun dikarenakan bahasa hukum adalah bagian dari bahasa indonesia yang moderen, maka dalam penggunaannya harus tetap, terang, monosemantik (hubungan antara ungkapan dan makna yang tetap dan tegas), dan memenuhi syarat estetika bahasa indonesia. Maka hal ini mengakibatkan penafsiran yang berbeda.

2. Sengketa ekonomi syariah tidak terselesaikan

Menurut peneliti bahwa kelemahan konsep akad ini akan mengakibatkan tidak terselesaikannya sengketa ekonomi syariah di Peradilan Agama, sebab ketidakpastiannya dalam memutuskan sengketa ekonomi syariah di karenakan konsep akad yang ada pada KHES belum sepenuhnya menjawab terkait

26 Uswatun Khasanah, "Penggunaan Akad Dalam Transaksi Jual Beli E-Commerce Dalam Perspektif Kompilasi Hukum Ekonomi Syariah (KHES)," IAIN Pekalongan, 2019, h. 27. 
subtansi masalah akad tersebut. Penyelesaian sengketa ekonomi syariah dalam bentuk akad mudahrabah dimana ketidak singkornnya dengan rukun akad pada KHES. yaitu mengenai ketentuan pasal 232 KHES tentang rukun akad mudharabah tidak mencantumkan objek akad sebagai salah satu rukun akad mudharabah. ketidaksingkornnya tersebut akan menjadi sangat ironis ketika akan menyelesaikan sengketa ekonomi. Peneyeselasian sengketa ekonomi syariah dalam bentuk akad mudharabah akan menjadi sangat sulit di capai apabila aturan hukumnnya tidak memiliki kejelasan. Hakim-hakim Pengadilan Agama yang memiliki background pemahaman ekonomi syariah dan paradigma hukum yang berbeda-beda. Maka akan berakibat Terhadap sengketa ekonomi syariah yang pada akhirnya nihilnya kepastian hukum. ${ }^{27}$

3. Pihak yang dirugikan

Menurut peneliti Bahwa dari kelemahan konsep akad pada KHES ini akan ada pihak yang dirugikan, sebab jika apa yang tetuang dalam pasal 607 pada KHES diamana pasal ini menyebutkan; "Biaya administrasi dibebankan kepada nasabah.'Pada pasal ini akan memicu adanya riba dan ini akan berdampak kepada nasabah yang ingin melakukan akad qard. Karena dalam pasal ini tidak diberikan batasan berapa persen biaya administrasi yang akan di ambil dari nasabah.

4. Tidak memberikan keterangan yang masif

Dalam KHES bahwa kafalah seperti pada Pasal 347 hanya sebatas pada kafalah atas diri dan kafalah atas harta, KHES tidak memberikan perincian definisi dari masing-masing jenis kafalah tersebut. Sedangkan dari segi literatur fiqih muamalah memberikan keterangan yang masif. 28

\section{B.5. Solusi Atas Kelemahan Konsep Akad Dalam Kompilasi Hukum Ekonomi Syariah (KHES)}

Dalam hal ini peneleti akan memberikan solusi atas kelemahan konsep akad dalam KHES, sebagaimana kita ketahui bahwa KHES merupakan landasan Hukum bagi sengketa ekonomi syariah yang ada di indonesia. KHES ini terdiri dari atas 790 pasal dan 5 bab. Berikut 5 bab dalam KHES yaitu: kecakapan hukum, pengampuan dan keterpaksaan, harta, akad, zakat dan hibah. Kemudian pada draft akhir menjadi 4 bab, di mana sistematika dalam Kompilasi Hukum Ekonomi Syariah (KHES) tersebut, terdiri atas: Pertama, Buku I tentang Subjek Hukum dan Amwal. Kedua, Buku II tentang Akad. Ketiga, Buku III Zakat dan Hibah. Keempat, Buku IV tentang Akuntansi syaria"eah. KHES terdiri dari 790 pasal.

27 Kelik Pramudya, "Strategi Pengembangan Ekonomi Syariah Melalui Penguatan Fungsi Pengadilan Agama Dalam Penyelesaian Sengketa," Journal of Chemical Information and Modeling, Vol. 5, No. 9, 2019 h. 100.

28 Usang M Assim and Julia Sloth-Nielsen, "Islamic Kafalah as an Alternative Care Option for Children Deprived of a Family Environment," African Human Rights Law Journal, Vol.14, No.2, 2014, h. 45 . 
Dilihat dari kandungan isi KHES di atas terdapat 790 pasal, sejumlah 648 pasal $(80 \%)$ adalah berkenaan dengan akad atau perjanjian. Dengan demikian materi terbanyak dari ketentuan-ketentuan mengenai ekonomi syariah adalah akad. Jika di perhatikan cakupan bab dan pasal dalam KHES, maka dapat dikatakan bahwa ruang lingkup ekonomi syariah meliputi:

"Ba'i, syirkah, mudharabah, muzara'ah, musaqqah, khiyar, ijarah, kafalah, hawalah, rahn, wadi'ah, ghasab dan ithlaf, wakalah, shuluh, pelepasan hak, ta'min, obligasi syariah, pasar modal, resdana syariah, sertifikasi bank syariah, pembiayaan multi jasa, qardh, pembiayaan rekening koran syariah, dan pensiun syariah, zakat dan hibah, serta akuntansi syariah."

KHES pada dasarnya berbicara soal akad atau transaksi yang merupakan positivisasi fiqh muamalah. Sehingga konsep akad yang terdapat di dalamnya tidak boleh terlepas dari prinsip-prinsip akad sebagaimana yang telah diatur dalam alKitab maupun al-Hadis. Karena kesyariahannya terletak pada aktualisasi prinsipprinsip yang terdapat pada sumber hukum islam tersebut. Peneliti merekomendasikan solusi kepada Team Penyusun KHES dengan melihat kelemahan atas konsep akad yang ada dalam KHES sebagai berikut:

1. Rukun dan Syarat akad pada Pasal 25 ayat (2)

Maka untuk solusi dari kejelasan makna sighat al aqd ini peneliti memberikan perbandingan dengan sighat al-aqd yang ada pada fiqih muamalah sebagaimana serapan KHES yang menganut kaidah fiqih muamalah. Dan untuk teks pada kata "dapat" harus dihilangkan karena akan mempengaruhi tafsir dari sighat akad tersebut, maka lebih tepatnya dirumuskan dengan" $a$ kad harus dilakukan dengan jelas, dalam bentuk lisan, tulisan dan/atau perbuatan."

2. Akad mudharabah pada pasal 232

Sebagai solusi peneliti merekomendasikan kepada Team penyusun KHES yaitu dengan menambah rukun akad mudharabah yang ada pada pasal 232 KHES yaitu, tujuan dan pokok, dan objek akad yang terdapat pada pasal 22 KHES. Karena rukun pertama dan kedua sebagaimana yang di maksud dalam pasal 232 tersebut masuk dalam unsur akad yang pertama yaitu pihak yang berakad yang terdapat pada pasal 22 ayat (1). Maka solusi dari rukun akad mudharabah pada pasal 232 KHES harus menambahkan objek akad, dan tujuan pokok akad sebagai salah satu rukun pada akad mudharabah.

3. Akad qard pada pasal 607

Maka peneliti merekomendasikan solusi dengan menambahkan ketentuan akad qardul hasan pada buku II di bab XXVII pada KHES sehingga akad qardul hasan bisa dipakai atau bisa dijadikan pasal baru pada buku II pada bab XXVII dan juga menambahkan batasan terhadap pasal 607 pada KHES, agar tidak ada penafsiran yang berlebih dari nasabah yang ingin membuat suatu akad qard. 


\section{Simpulan}

Setelah mengintip dan mengutip beberapa pokok bahasan dari Bab ke Bab dalam skripsi dengan tema Konsep Akad dalam Fiqih Muamalah (Studi Kritis Terhadap Peranapan Konsep Akad dalam Kompilasi Hukum Ekonomi Syariah KHES. Maka peneliti menyimpulkan bahwa Sejarah dibentuknya Kompilasi Hukum Ekonomi Syariah (KHES) tidak dapat terlepas dari amanat Pasal 49 UU No. 3 Tahun 2006 tentang Perubahan Atas UU No. 7 Tahun 1989 tentang Peradilan Agama . KHES tentu saja bukan kitab suci yang tidak bisa diubah-ubah, . KHES ini terdiri dari atas 790 pasal dan 5 bab. Berikut 5 bab dalam KHES yaitu: kecakapan hukum, pengampuan dan keterpaksaan, harta, akad, zakat dan hibah. Kemudian pada draft akhir menjadi 4 bab, di mana sistematika dalam Kompilasi Hukum Ekonomi Syariah (KHES) tersebut, terdiri atas: Pertama, Buku I tentang Subjek Hukum dan Amwal. Kedua, Buku II tentang Akad. Ketiga, Buku III Zakat dan Hibah. Keempat, Buku IV tentang Akuntansi syaria"eah. KHES terdiri dari 790 pasal.Dilihat dari kandungan isi KHES di atas terdapat 790 pasal, sejumlah 648 pasal (80\%) adalah berkenaan dengan akad atau perjanjian. KHES ini terdapat kelemahan dalam Subtansi akadnya yaitu dalam rukun dan syarat akad pada pasal 25 ayat (2), akad Mudharabah pada pasal 232 tentang rukun akad mudharabah, akad qard pasal 607 dan pasal 612-613, kafalah,dan pada pasal 347. Maka kosekuensi dari kelemahan konsep akad yang ada dalam KHES tersebut berupa; Penafsiran yang berbeda-beda, Sengketa ekonomi syariah tidak terselesaikan, Pihak Yang Dirugikan dan tidak memberikan keterangan yang masif. Maka solusi dari kelemahan konsep akad dalam KHES yaitu: Untuk pasal 25 ayat (2) mengenai rukun dan syarat akad Maka solusi dari kejelasan makna sighat al aqd ini peneliti memberikan perbandingan dengan sighat al-aqd yang ada pada fiqih muamalah sebagaimana serapan KHES yang menganut kaidah fiqih muamalah. Dan untuk teks pada kata "dapat" harus dihilangkan karena akan mempengaruhi tafsir dari sighat akad tersebut, maka lebih tepatnya dirumuskan dengan"akad harus dilakukan dengan jelas, dalam bentuk lisan, tulisan dan/atau perbuatan", dan untuk rukun akad mudharabah pada pasal 232 KHES harus menambahkan objek akad, dan tujuan pokok akad sebagai salah satu rukun pada akad mudharabah, Dan menambahkan ketentuan akad qardul hasan pada buku II di bab XXVII pada KHES kemudian memberikan batasan terhadap pasal 607 agar tidak ada penafsiran yang berlebih dan terakhir mengenai kafalah pada pasal 347 harus memberikan kejelasan secara rinci.

\section{Referansi:}

Abdul Ghofur, "Pengantar Ekonomi Syariah: Konsep Dasar, Paradigma, Pengembangan Ekonomi Syariah," 2017.

Abdul Mughits, “Kompilasi Hukum Ekonomi Syari’ah (KHES) Dalam Tinjauan Hukum Islam," Al-Mawarid Journal of Islamic Law, Vol.18, No.1, 2008.

Andy Triyawan, “Konsep Qard Dan Rahnmenurut Fiqhalmadzhahib," Ijtihad: Jurnal Hukum dan Ekonomi Islam, Vol.8, No.1, 2014.

Any Widayatsari, "Akad Wadiah Dan Mudharabah Dalam Penghimpunan Dana Pihak Ketiga Bank Syariah," Economic: Journal of Economic and Islamic Law, Vol.3, No.1, 2013. 
Assim, Usang M and Julia Sloth-Nielsen, "Islamic Kafalah as an Alternative Care Option for Children Deprived of a Family Environment," African Human Rights Law Journal, Vol.14, No.2, 2014.

Bagus Ahmadi, "Akad Bay', Ijarah Dan Wadi'ah Perspektif Kompilasi Hukum Ekonomi Syariah (KHES)," Epistemé: Jurnal Pengembangan Ilmu Keislaman, Vol.7, No.2, 2012.

Edhy Rustan, "Analisis Penggunaan Bahasa Indonesia Laras Hukum Pada Putusan Perkara Ekonomi Syariah Pengadilan Agama Makassar", Center for Open Science, 2016.

Husni Kamal, "Penyelesaian Sengketa Ekonomi Syariah Pasca Putusan MK No. 93/Puu-X/2012 (Analisis Putusan Pengadilan Agama Cilegon No. 411/Pdt. G/2013/PA. Clg)," Universitas Islam Negeri" Sultan Maulana Hasanuddin" Banten, 2018.

Ifa Lathifa Fitriani, “Kompilasi Hukum Ekonomi Syariah Dalam Pemaknaan Hukum Islam Dan Sistem Hukum Positif di Indonesia," Supremasi Hukum: Jurnal Kajian Ilmu Hukum, Vol.5, No.1, 2020.

Johar Arifin, "Substansi Akad Dalam Transaksi Syariah," Al-Amwal: Jurnal Ekonomi dan Perbankan Syari'ah, Vol.6, No.1, 2016.

Kelik Pramudya, "Strategi Pengembangan Ekonomi Syariah Melalui Penguatan Fungsi Pengadilan Agama Dalam Penyelesaian Sengketa," Journal of Chemical Information and Modeling, Vol. 5, No. 9, 2019.

M.Ichsanuddin, "Tinjauan Hukum Islam Terhadap Wanprestasi Dalam Hukum Perdata", IAIN Sunan Ampel Surabaya, 1988.

Mughits, "Kompilasi Hukum Ekonomi Syari'ah (KHES) Dalam Tinjauan Hukum Islam."

Mutiara Citra, Rika Lestari, and Rahmad Hendra, “Tinjauan Yuridis Terhadap Kawin Kontrak Dalam Perspektif Hukum Perjanjian Dan Hukum Islam”, Riau University, 2016.

Nashihul Ibad Elhas, "Kompilasi Hukum Ekonomi Syariah (KHES) Dalam Tinjauan Umum Hukum Islam," Al-Tsaman: Jurnal Ekonomi Dan Keuangan Islam, Vol.2, No.1, 2020.

Novi Ratna Sari, "Komparasi Syarat Sah Nya Perjanjian Menurut Kitab UndangUndang Hukum Perdata Dan Hukum Islam," Jurnal Repertorium, Vol.4, No.2, 2017.

Nugraha Pranadita, “Akad-Akad Dalam Kompilasi Hukum Ekonomi Syariah (KHES) Dan Implementasinya Pada Sebuah Warung," Jurnal Hukum, Vol.32, No.2, 2016.

Popon Srisusilawati dan Nanik Eprianti, "Penerapan Prinsip Keadilan Dalam Akad Mudharabah Di Lembaga Keuangan Syariah," Law and Justice, Vol.2, No.1, 2017.

Rahayu Ningsih Eka Putri, "Penggunaan Kompilasi Hukum Ekonomi Syariah (Khes) Dalam Putusan Perkara Perlawanan Eksekusi Lelang Hak Tanggungan Pembiayaan Fasilitas Murabahah (Studi Kasus Putusan Nomor: 1301/Pdt. G/2019/PA. JP)," IAIN Purwokerto, 2020.

Rahmani Timorita Yulianti, "Asas-Asas Perjanjian (Akad) Dalam Hukum Kontrak Syari'ah," Jurnal Fakultas Hukum UII, Vol.2, No.1, 2008. 
Taufiq Risal, "Peningkatan Peran Perbankan Syariah Dengan Menggerakkan Sektor Riil Dalam Pembangunan," Accumulated Journal (Accounting and Management Research Edition), Vol.1, No.1, 2019.

Uswatun Khasanah, "Penggunaan Akad Dalam Transaksi Jual Beli E-Commerce Dalam Perspektif Kompilasi Hukum Ekonomi Syariah (KHES)," IAIN Pekalongan, 2019. 